\title{
Sigmund Freud ja psühhoanalüütiline naljauurimine
}

\author{
Astrid Tuisk
}

Naljauurimine jääb mitme teadusala piirimaile. Käsitlusi naljadest avaldavad nii folkloristid, sotsioloogid, psühholoogid, kirjandusteadlased kui teisedki. Käesolevalt mõningaist probleemidest alal, kus puutuvad kokku psühholoogiline ja folkloristlik naljavaatlus.

Psühholoogilistes ja folkloristlikes uurimustes lähtutakse erinevatelt alustelt. Esimeses huvitutakse mitte niivõrd naljatekstist, kuivõrd funktsioonist ja kohast, mis ta hõivab inimese juures, kes seda nalja loeb, kuulab, edasi annab. Tegeldakse anekdoodi kontekstiga ehk täpsemalt tegeldakse konteksti selle osaga, mis puudutab indiviidi ning nalja mõju talle. Erinevate psühholoogiliste suundade esindajad, aga ka strukturalistid, kaasajal moodsad antroposoofid jt. piiritlevad vaatlusalust veelgi ning käsitlevad rahvajutte sh nalju kui alateadvuslikke protsesse ja hingeaparaadi väljendusi (Holbek 1993: 225). See on ka psühhoanalüütilise (nimetatud ka freudistlikuks) meetodi põhialus.

Psühhoanalüütiline suund uurimismeetodina sai alguse selle sajandi algul psühhiaater Sigmund Freudi töödest. Nii folkloori, kirjandusteoste kui kogu kultuuri põhjusi hakati otsima inimeste sisemaailmast. Meetod leiab järgijaid tänapäevani, rahvajuttudest eriti nalja- ja muinasjutuuurimises. Psühholoogid, psühhoterapeudid ning teisedki analüüsivad rahvajuttude mõju tänapäevastele kuulajatele ning rääkijatele (nt Bruno Bettelheim uurimusega Kinder brauchen Märchen), vaatlevad muinasjutu sümboolikat (nt William Desmonde Jack and the beanstalk). Rohkearvulisi vaatlusvõimalusi esindagu mõned tunnuslikud artiklipealkirjad Das Mädchen ohne Hände. Ein Märchen ohne Inzest (Heino Gehrts), Into the Endzone for a Touchdown: A Psychoanalytic Consideration of American Football (Alan Dundes), Sexual Symbolism in the Language of the Air Force Pilot: A Psychoanalytic Approach to Folk Speech (S. G. Kenagy).

Nalju ning psühhoanalüütilist lähenemisviisi neile käsitleb Freud teoses Der Witz und seine Beziehung zum Unbewußten (Nali ja selle suhe alateadvusega; tsiteerimisel kasutatakse Hamburgis 1958. a. ilmunud väljaannet). Käsitletakse nii kirjanduslikke nalju kui pärimuslikke naljandeid ning anekdoote, nii et siinkohal peame otstarbekaks termini der Witz vastandiks kasutada üldmõistet nali. Kui teiste folkloorizhanride vaatlusel lähtub Freud enamjaolt trükitekstidest (nt Grimmide Kinder- und Hausmärchen, Anderseni muinasjutud), siis näiteks juudianekdoote tundis Freud hästi ja rääkis neid ka ise meelsasti. Teos on leidnud rohkesti järgijaid just psühholoogide seast, seda on nimetatud tsiteeritavaimaks naljauurimuseks (Knuuttila 1982, 123).

Sigmund Freudi järgi on inimese psüühika aluseks alateadvuslike naudinguhimude lakkamatud konfliktid reaalsuse printsiibiga, millega teadvus kohandub. Assotsiatsioonidena esinevad need püüdlused unenägudes, aga ka mütoloogias ja folklooris, ning neid on võimalik lahti seletada, tõlgendada psühhoanalüüsi abil.

Peatähelepanu pöörab autor materjali kontekstile, tõdedes, et iga konkreetne rahvajutt avaldab hingeelule erinevat mõju. Sellest tuletab Freud subjektiivsed tingimused nalja loomise, edasiandmise ja vastuvõtmise kohta. Inimeste eriilmelisus väljendub selles, kuidas konkreetne anekdoot neile mõju avaldab. Olulised pole mitte teatud nalja objektiivsed omadused, vaid meie 
teadvuse tegevus seda nalja interpreteerides. Nalja vastuvõtmine meie teadvuse poolt on omakorda nii oluline selle poolest, et anekdootides leiavad väljapääsu alateadvuslikud tõrjutud soovid. Nii on nalju peetud tsensuuri kaotajaiks, reaalses elus allasurutud soovide avalikustajaks. Need naljades tagaplaanile tõrjutud soovid mõjutavad erinevalt iga inimest ning panevad siis kelle vähem, kelle rohkem selle üle lõbu, naudingut tundma. Naer ning eufooria, mida nalja lõppedes tajutakse, tuleneb inimese vabanemisest teda kammitsenud pingetest. Takistus, mis seejuures ületatakse, võib olla nii välimine kui sisemine. Kirjeldatu kujutab endast tervet protsessi, mida Freud on nimetanud naljatööd (Witzarbeit; vrd unetöö - Traumarbeit), mille käigus transformeeritakse neid varjatud püüdlusi.

Freud eraldab naljade tehnika ja tendentsi. Nali võib oma tendentsilt ehk funktsioonilt ja rõhuasetuselt olla obstsöönne, agressiivne (vaenulik), küüniline (kriitiline või blasfeemiline) või skeptiline (Freud 1958: 93-94). Siinkohal veidi lühendatult juudianekdoot, mida Freud nimetab sügavalt, pessimistlikult küüniliseks, ning tema kommentaar sellele. Kõva kuulmisega mees konsulteerib arstiga, kes paneb talle diagnoosi: mees joob liiga palju viina ning on sellepärast kurt. Arst soovitab tal vähem juua ning mees võtabki teda kuulda. Mõne aja pärast kohtab arst meest tänaval ning küsib valjusti, kuidas tal läheb. "Tänan küsimast," vastab mees "aga te ei pea nii karjuma, härra doktor, ma jätsin joomise maha ning kuulen jälle hästi." Vähe aja pärast situatsioon kordub. Doktor küsib tasasel häälel mehe tervisliku seisundi kohta, märkab aga, et mees ei saa tast aru. "Mulle paistab, et te joote jälle," karjub doktor talle kõrva "ja seepärast ei kuule te jälle." "Teil on õigus," vastab mees. "Ma hakkasin jälle viina jooma, aga ma tahaksin teile öelda, miks. Niikaua kui ma ei joonud, kuulsin ma hästi; aga kõik, mida ma kuulsin, polnud pooltki nii hea kui viin. "Jutustamiskunst teenib naeru esilekutsumist. Tagaplaanil kõlab aga kurb küsimus: kas sel mehel pole mitte omal kombel õigus? See on juudi lootusetu õnnetus, mis selles pessimistlikus anekdoodis ette mängitakse." (Freud 1958: 92-93) Jutu teemana võiks nimetada alkoholi ja selle kütkeist pääsemise raskust, kuid nalja tuum asub selle lõpus (vrd. unenägude tõlgendamist, mida samuti alustatakse lõpust).

Tehnika all vaatleb Freud koomilise mõjulepääsemiseks kasutatavaid vahendeid. Nagu unenäole, nii ka anekdoodile on iseloomulik tihendus, kokkusurutus (Verdichtung), kaudne kirjeldus, st ümberütlemine (indirekte Darstellung) ja nihe (Verschiebung). Et antud uurimus kujutab tõsist ja põhjalikku naljaanalüüsi, näitab naljatehnika võtteid tutvustav tabel (Freud 1958: 33) ning selle edasine lahtiseletus. Lisaks eelpool mainitule pööratakse tähelepanu unifitseerimisele, absurdsusele, vastandusele. Sõnade mitmetähenduslikkusel põhineb järgmine anekdoot: Kaks juuti kohtuvad supelmaja lähedal. "Kas sa võtsid vanni?" küsib üks. "Kuidas," vastab teine seepeale "kas üks puudub?" (Freud 1958: 39)

Põhiülesandeks jääb aga ikka vastuste otsimine küsimustele mille üle me naerame ning miks me just selle üle naerame. Nii märgib Freud: Nali avaldab mõju sellele, kes teda kuulab, iseloomustab selle psü̈hilist seisundit, kes selle lõi, kes seda jutustab, kellele see meelde tuli (Freud 1958: 113). Nalja interpreteerimise kolmelülilist ahelat toonitatakse naljade kommunikatiivsusest rääkides. Kirjanduslikke nalju aluseks võttes kirjutab Freud enda loodud nalja üle naermise võimatusest, kuna seal ilmsiks tulev puudutab tegijat liiga sügavalt. Samas ei saa nalja ainult iseenda teada jätta, sest selle avaldamise tung (Trieb zur Mitteilung) on suur. Nali saab eksisteerida vaid kommunikatiivses protsessis. 


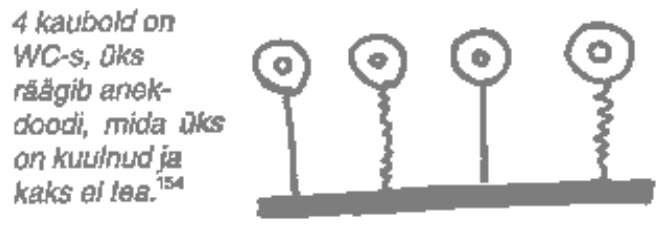

Freud heidab oma eelkäijatele ette naljade pidamist nende kasutajaist sõltumatuks. Inimene kontrolliks justkui täielikult ringluses olevat nalja, on sellest üle. Freudi arvamus on vastupidine inimene on naljade meelevallas, naljad mõjutavad teda. Esimest lähenemist võiks nimetada naljade väliseks vaatluseks ning seda harrastavad just folkloristid, kuna tegeldakse otseselt naljatekstiga (vastupidi siis enamasti psühholoogidele, kes tegelevad vaid psüühikaga). Kuid on ju selge, et üks ja sama nali paneb ühe inimese luksumiseni naerma, teise aga, kes võib olla sama vana, samasooline ning samast sotsiaalsest keskkonnast, jätab täiesti külmaks. Siit tulenevad mitmed psühhoanalüüsiga tegelejate edasised mõttearendused. Üks koolkonna väljapaistvamaid esindajaid, ameeriklane Gershon Legman juhindub naljauurijate poolt teisendatud vanasõnast Ütle mulle, mille üle sa naerad, ja ma ütlen, kes sa oled. Peateoses Rationale Of The Dirty Joke:A Analysis Of Sexual Humor vaatleb Legman meelisanekdoote. Eksperimendi käigus palutakse rääkida oma lemmikanekdoot või nali, mis esimesena meelde tuleb (Knuuttila 1982: 124). Neid analüüsitakse, sest vastav anekdoot peaks valgust heitma inimpsüühika varjatuimatesse soppidesse.

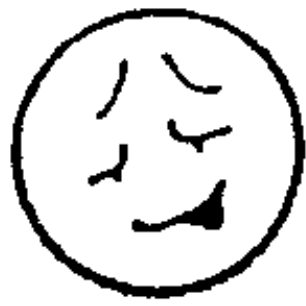

Häbelik Nagu eelnevast järeldub, nähakse naljade ning alateadvuse vahel vastavust. Selgub ka, et naljade põhjal on võimalik teha järeldusi nende looja ning kasutaja psüühika kohta. Saame me aga psüühikast lähtudes panna paika hüpoteese sellele inimesele sümpatiseerivaist anekdootidest? Teades naljade loomise, omandamise ja kasutamise kulgu, on ehk võimalik leitud seaduspärasustele toetudes säilinud naljade põhjal rekonstrueerida näiteks möödunud ajastute inimeste psüühikat. Psühhoanalüütilise analüüsi rakendus põhineb küll Freudi poolt väljatöötatul, ületab aga kaugelt tema poolt pakutu ning ehk ka loodetu.

Freudismi ja teiste uurimissuundade põhialustes on mitmeid olulisi lahkuminekuid. Välja olgu toodud üks, vastandus nali ja tõsielu. Nalju vaadeldakse sageli kui elu kunstilist peegeldajat, just sotsioloogiliste suundade esindajate töödes. Anekdoot kajastab nende järgi konkreetset ühiskonda, näidates, mida vihati, kardeti, eitati jne. Psühhoanalüütilises suunas nalja ja tõsielu vastandus üldse puudub. Tegelikkusega on tegemist niivõrd, kuivõrd meie seda kogeme, tunnetame, sest tegeldakse inimese psüühikas toimuvate protsesside ja selle tulemuse vaatlusega. Selles suhtes pole objektiivse reaalsusega üldse seost. Naljamaailm ning naljatekst saab oluliseks alles seejärel, kui ta on töödeldud meie teadvuse poolt.

Eespool on viidatud naljaterminite kõrval ka unenäo analüüsis kasutusel olevatele mõistetele. Muidugi pole juhuslik, et Freud nalju analüüsima sattus. Tema unenäoteooria sarnaneb huumoriteooriale ning algtõuke naljadest kirjutamiseks andis W. Fliessi märkus Unenägude tõlgendamise kohta: Unenäod paistavad vahel nii naljakad. (Oring 1987: 271)

Kaheldamatult pani Sigmund Freudi teooria aluse uuele meetodile rahvajutu-uurimises, mis leidis rohkelt järgijaid. Selle soosituse põhjusi on mitmeid. Räägitud on ühiskonna- ja sotsiaalteaduste uurimismeetodite kriisist, teadusalade piiride ähmastumisest. Vanad, traditsiooniliste meetodite abil otsitud nalja-, aga ka kogu pärimuse seletused ei suutnud rahuldada naljauurijaid, eriti uut "mässumeelset maailma" defineerivalt esindava anekdoodi puhul. Neile heideti ette võimetust tungida asja sisuni,

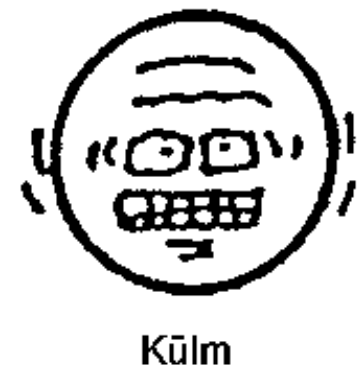

Kūlm 
olemuseni. Uued naljainterpretatsioonid annavad võimaluse iseenda ning oma maailma mõtestamiseks just kaasajal, kus kõik on lubatud ning suhteliseks kuulutatud. Psühhoanalüüs sai areneda vaid uusaja ühiskonnas. Teda on nimetatud nü̈̈disaja kaose nähtuseks ning katseks kõik pahupidi pöörata (Evola 1994: 41). Psühhoanalüüs ei paku võrdlusi, ei otsita mõistmist, arusaamist, vaid erinevatele nähtustele põhjuse-tagajärje suhtele toetudes seletusi. Iseasi on, kas juba loomuldasa eitusel põhinevat anekdooti saab seletada teise pahupidipööraja abil. Kas eituse eitus on jaatus või on peegelpildi peegelpilt ikkagi lihtsalt valet pidi? Kaheldamatu on aga see, et Freud teisendas inimesesse suhtumise põhialuseid.

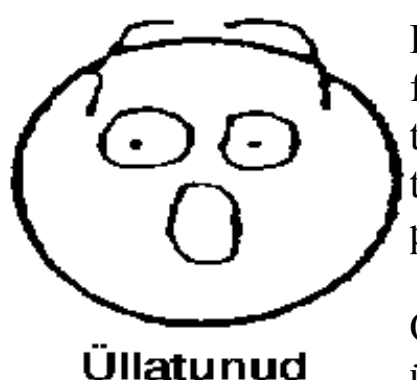

Freudismi kriitikud heidavad meetodile nii kirjandus- kui ka folklooritekstide analüüsi puhul ette ühekülgsust ning soovitavad vaadelda teoseid neist enestest lähtudes, mitte kohaldades nende uurimiseks teiste teaduste kogemusi. Ka ei saa folklooritekste ammendavalt analüüsida positivistliku äraseletamise varal (Peep 1978:144).

Olgu naljade uurijatel kuitahes erinevaid arusaamu nende tõlgendamisest, ühes on kõik ühel meelel: naljade põhiolemusse kuulub mängulisus ning rõõm. Ehk Freudi-uurija Marthe Roberti sõnadega: Naljade psühholoogiline tähtsus seisneb rõõmul, mida nad valmistavad ja nagu iga lõbu, nii viivad ka naljad täiskasvanuid nukralt, kuid tõsimeelselt tagasi lapsepõlvemängude juurde.

Kuid lõpetada ei saa ilma psühhoanalüütilisele naljakäsitlusele mingitki hinnangut andmata. Võib ju küsida, on see teooria õige või vale, peab ta paika või ei. Mida rohkem tekib uusi anekdoote, mida sürrealistlikumaks ning agressiivsemaks need muutuvad, seda teravamalt kerkib igihaljas küsimus: "Miks me selle üle naerame?" Arvan, et sellele vastamiseks on otstarbekas meenutada Sigmund Freudi ning tema teost "Der Witz und seine Beziehung zum Unbewussten." Siinkohal tsitaat Freudi tõlgendajalt Geoffrey Hartmanilt: Kui unenägu pole püha ja kui tõlgendus seda näitab, siis see tõlgendusvõime, mis

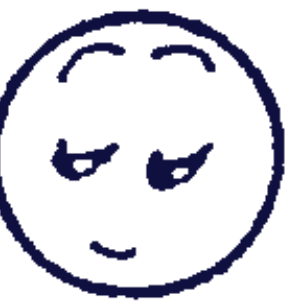

Uudishimulik end meetodipärastab ja universaalseks muudab, on midagi väga lähedast pühadusele (Hartman 1992: 1473).

\section{Kirjandus}

Holbek, Bengt. Enzyklopädie des Märchens. Bd. 7. Berlin, New York 1993.

Knuuttila, Seppo. Kaskut ja vitsit. Kertomusperinne. Pieksämäki 1982.

Oring, Elliott. Enzyklopädie des Märchens. Bd. 5. Berlin, New York 1987.

Evola, Julius. Esseid. Vikerkaar. Nr. 4, 1994.

Peep, Harald. Tähtraamat. Tallinn 1978.

Hartman, Geoffrey. Freud tõlgendaja silmis. Akadeemia. Nr. 7, 1992. 